\title{
FRESH FROZEN PLASMA AS A SUCCESSFUL ANTIDOTAL SUPPLEMENT IN ACUTE ORGANOPHOSPHATE POISONING
}

\author{
Slavica VUČINIĆ ${ }^{1}$, Milica ZLATKOVIĆ ${ }^{1}$, Biljana ANTONIJEVIĆ ${ }^{2}$, Marijana ĆURČIĆ ${ }^{2}$, and \\ Bogdan BOŠKOVIĆ ${ }^{1}$
}

National Poison Control Centre, Medical Faculty, Military Medical Academy, University of Defence ${ }^{1}$, Department of Toxicology "Akademik Danilo Soldatović, Faculty of Pharmacy, University of Belgrade², Belgrade, Serbia

Received in March 2013

CrossChecked in April 2013

Accepted in April 2013

\begin{abstract}
Despite improvements to intensive care management and specific pharmacological treatments (atropine, oxime, diazepam), the mortality associated with organophosphate (OP) poisoning has not substantially decreased. The objective of this examination was to describe the role of fresh frozen plasma (FFP) in acute OP poisoning. After a deliberate ingestion of malathion, a 55-year-old male suffering from miosis, somnolence, bradycardia, muscular fasciculations, rales on auscultation, respiratory insufficiency, as well as from an inhibition of red blood cell acetylcholinesterase (AChE) and plasma butyrylcholinesterase (BuChE), was admitted to hospital. Malathion was confirmed in a concentration of $18.01 \mathrm{mg} \mathrm{L}^{-1}$. Apart from supportive measures (including mechanical ventilation for four days), antidotal treatment with atropine, oxime - pralidoxime methylsulphate $\left(\right.$ Contrathion $\left.^{\circledR}\right)$, and diazepam was administered, along with FFP. The potentially beneficial effects of FFP therapy included a prompt increase of BuChE activity (from $926 \mathrm{IU} \mathrm{L}^{-1}$ to $3277 \mathrm{IU} \mathrm{L}^{-1}$; reference range from $7000 \mathrm{IU} \mathrm{L}^{-1}$ to $19000 \mathrm{IU} \mathrm{L}^{-1}$ ) and a reduction in the malathion concentration, followed by clinical recovery. Due to BuChE replacement, albumin content, and volume restitution, FFP treatment may be used as an alternative approach in patients with acute OP poisoning, especially when oximes are not available.
\end{abstract}

KEY WORDS: acetylcholinesterases, albumin, butyrylcholinesterase, malathion, oximes

The conventional approach to organophosphate (OP) poisoning treatment involves efforts to counteract the effects of excessive acetylcholine (ACh) accumulation and the overstimulation of cholinergic neurons caused by irreversible acetylcholinesterase (AChE) inhibition. Atropine effectively reduces muscarinic signs, while oximes reactivate inhibited $\mathrm{AChE}$ and directly detoxify unbound OPs (1). Despite the use of these antidotes and improvements to intensive care, the mortality associated with OP poisoning remains high and calls for new alternative treatments $(2,3)$. Fresh frozen plasma (FFP) or albumin, acting as a bioscavenger to clean up circulatory OPs, has been evaluated as an alternative treatment modality, but the few studies that have investigated it are controversial and need to be clarified $(4,5)$.

\section{SUBJECTS AND METHODS}

A 55-year-old farmer was brought to the National Poison Control Centre with miosis and an organic solvent-like odour. The patient complained of nausea, 
vomiting, and diarrhoea, but his vital signs were normal: blood pressure $140 \mathrm{~mm} \mathrm{Hg} / 70 \mathrm{~mm} \mathrm{Hg}$, pulse $70 \mathrm{bpm}$, oxygen saturation $\left(\mathrm{sO}_{2}\right) 96 \%$. Three hours earlier, he drank $100 \mathrm{~mL}$ of pesticide formula, containing $600 \mathrm{~g} \mathrm{~L}^{-1}$ of malathion. A gastric lavage was performed, followed by an administration of $50 \mathrm{~g}$ of activated charcoal and an evacuation of white coloured solution. After admission to the Intensive Care Unit $4 \mathrm{~h}$ after ingestion, he was somnolent, spontaneously breathing, with copious bronchial secretion, pinpoint pupils, muscle fasciculations, hypotension ( $90 \mathrm{~mm} \mathrm{Hg} / 70 \mathrm{~mm} \mathrm{Hg}$ ), pulse $90 \mathrm{bpm}$, and had a respiratory rate of $25 \mathrm{~min}^{-1}$. Apart from supportive measures, he received $12 \mathrm{mg}$ of atropine during the first $30 \mathrm{~min}$, followed by a continuous infusion of atropine. The patient was administered $2 \mathrm{~g}$ of pralidoxime methylsulphate as a loading dose, followed by $500 \mathrm{mg} \mathrm{h}^{-1}$ in a continuous infusion and fresh frozen plasma (two bags, from $220 \mathrm{~mL}$ to $250 \mathrm{~mL}$ every $12 \mathrm{~h}$ for 2 days; total of 8 bags). Due to the development of respiratory insufficiency $\left[\mathrm{pH} 7.54, \mathrm{pO}_{2} 50, \mathrm{~s} \mathrm{O}_{2} 89 \%, \mathrm{pCO}_{2} 32\right.$, actual base excess (ABE) 4.9] and copious bronchial secretion, the patient was intubated and mechanical ventilation was initiated. Routine laboratory tests were within normal limits.

\section{RESULTS}

Initially, the number of red blood cell (RBC) AChE and plasma BuChE showed an activity of $1862 \mathrm{IU} \mathrm{L}^{-1}$ (reference range from $4000 \mathrm{IU} \mathrm{L}^{-1}$ to $8000 \mathrm{IU} \mathrm{L}^{-1}$ ) and $926 \mathrm{IU} \mathrm{L}^{-1}$ (reference range from $7000 \mathrm{IU} \mathrm{L}^{-1}$ to $\left.19000 \mathrm{IU} \mathrm{L}^{-1}\right)$, respectively, with a significant reduction of AChE activity to $903 \mathrm{IU} \mathrm{L}^{-1}$ and an increase of BuChE to $3227 \mathrm{IU} \mathrm{L}^{-1}$ after $6 \mathrm{~h}$ (and the first dose of fresh frozen plasma). On day one, malathion was confirmed in the blood by the liquid chromatography-mass spectrometry method (LC-MS) at a concentration of $18.01 \mathrm{mg} \mathrm{L}^{-1}$. After $5 \mathrm{~h}$, the concentration of malathion was $11.25 \mathrm{mg} \mathrm{L}^{-1}$, and after the second dose of plasma, the level of malathion was $1.21 \mathrm{mg} \mathrm{L}^{-1}$. After the third dose of FFP, malathion concentrations reduced even further $\left(0.07 \mathrm{mg} \mathrm{L}^{-1}\right.$ and $0.02 \mathrm{mg} \mathrm{L}^{-1}$ ), while on day two, it was no longer detected. Mean BuChE level of FFP was (10868 \pm 1078$) \mathrm{IU} \mathrm{L}^{-1}$, while the total albumin given amounted to $82 \mathrm{~g}$.

AChE activity continued to decrease, whereas BuChE responded well to FFP therapy (from 926 IU L ${ }^{-1}$, the level increased to $1576 \mathrm{U} \mathrm{L}^{-1}$ after the first, and from $3227 \mathrm{IU} \mathrm{L}^{-1}$ to $5816 \mathrm{IU} \mathrm{L}^{-1}$ after the second dose) (Figure 1).

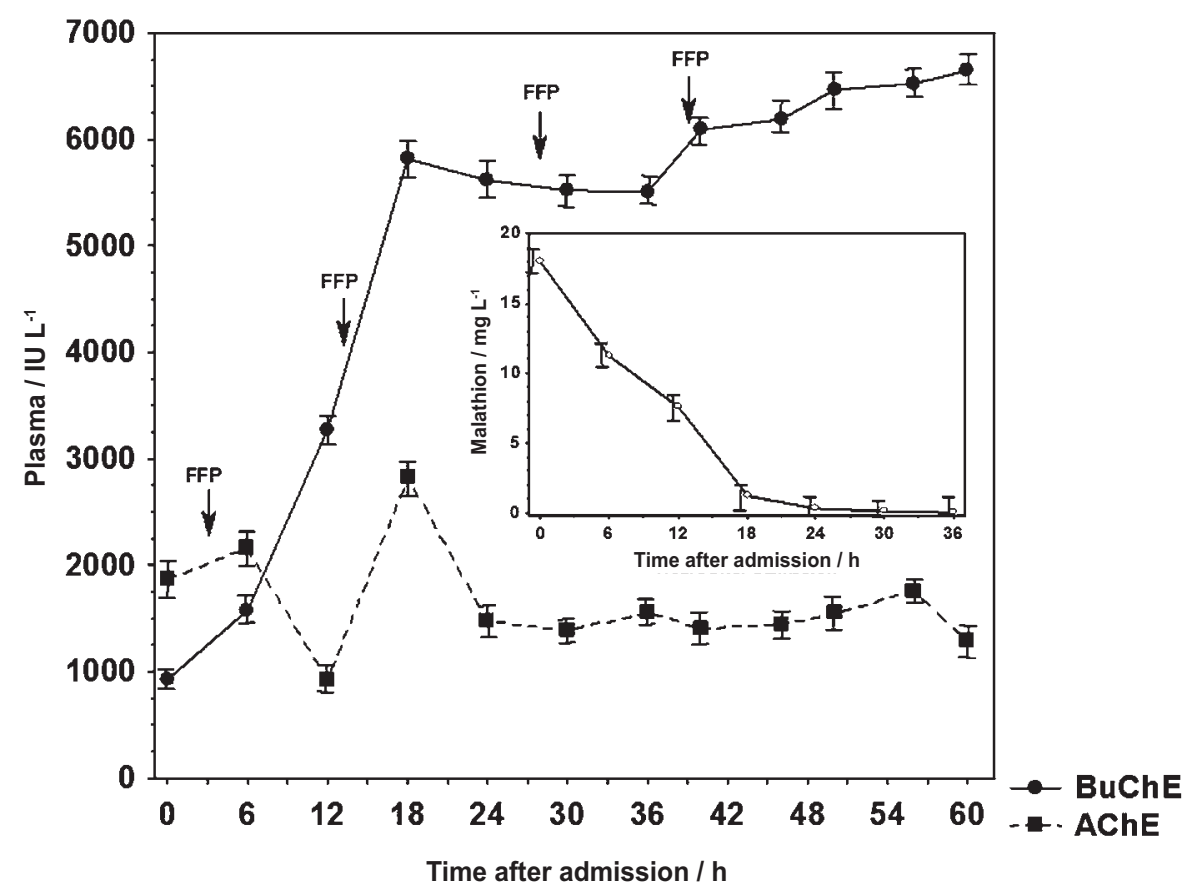

Figure $1 B u C h E$ and $A C h E$ activity $\pm S D$, with the malathion concentration $\pm S D$ in blood 
In order to evaluate the capacity of FFP for binding malathion to albumin (mean value $4.1 \mathrm{~g} \mathrm{~L}^{-1}$ ), a water solution of insecticide was incubated in vitro with FFP in a molar ratio 1:1 of its albumin content. The mixture was kept in a water bath at $37^{\circ} \mathrm{C}$ for various time intervals ranging from $1 \mathrm{~h}$ to $24 \mathrm{~h}$. The unbound malathion concentration was determined by the LCMS method. The results showed that malathion was bound to FFP at a concentration of $200.8 \mathrm{mg} \mathrm{L}^{-1}$, with $\mathrm{at}_{1 / 2}$ of $2.1 \mathrm{~h}$.

The clinical recovery was gradual. Mechanical ventilation was no longer necessary from day four, and only small daily doses of atropine were needed. The total atropine dose was $735 \mathrm{mg}$, and pralidoxime was used for four days. The patient's condition improved steadily and he was discharged from the hospital on day seven.

\section{DISCUSSION}

Butyrylcholinesterase functions as a natural bioscavenger that binds OPs stoichiometrically and thus inactivates them. The advantage of the prophylactic use of purified human $\mathrm{BuChE}$ was confirmed in various OPs, including soman, sarin, and tabun. A single dose of $\mathrm{BuChE}$ was able to maintain therapeutic concentrations for at least four days, protecting humans from an exposure of $2 \times \mathrm{LD}_{50}$ to $5 \times \mathrm{LD}_{50}(3$, 6 ). An experimental study on guinea pigs confirmed that the nerve agents sarin, soman, cyclosarin, and tabun formed phosphorylated adducts with a tyrosine residue on albumin when incubated with human plasma in vitro. Albumin served as a relatively longlived biological marker not only for nerve agents (7), but also for dichlorvos (8).

No human trials involving BuChE have been conducted due to the high costs and large quantity needed for the inactivation of OPs. An alternative approach would be to use FFP. In a prospective clinical study, Güven et al. (4) applied FFP with atropine and pralidoxime in 12 patients with OP poisoning, while 22 patients were given atropine and oximes (controls). In the control group, the mortality was $14.3 \%$, and intermediate syndrome (IMS) was $28.6 \%$, while neither lethal outcomes nor IMS were registered in the group with FFP. Furthermore, plasmapheresis with FFP was used on a patient with fenitrothion poisoning who developed sepsis. After plasma exchange therapy, ChE levels increased and the patient's clinical condition resulted in a complete recovery (9).
Contrary to this, the results of an open-labelled pilot randomized trial involving the comparison of FFP, albumin, and saline in sixty patients with acute OP poisoning did not show any favourable effects on the clinical outcomes (5). Despite a significant increase in BuChE levels with FFP, a greater number of IMS cases were observed, and there were no differences in atropine requirement, duration of mechanical ventilation, hospital stay or mortality. Two explanations for the unsuccessful treatment were offered: ageing of OP-ChE and OP-albumin complex dissociation (7).

Fulton (10) attempted to explain the favourable effect of FFP found by Güven et al. $(4,9)$ through discussing "the secret ingredient" and suggested that aggressive volume resuscitation with $\mathrm{BuChE}$ serves as a possible scavenger; however, the author did not comment on the same presumed role of albumin.

Our patient was severely poisoned by malathion, with pronounced muscarinic and nicotinic effects and a marked inhibition of $\mathrm{AChE}$ and BuChE. The malathion concentration in the patient's blood was $18.01 \mathrm{mg} \mathrm{L}^{-1}$, which was reduced rapidly by an administration of FFP. This concentration is close to the malathion blood level of $23.9 \mathrm{mg} \mathrm{L}^{-1}$ found antemortem in a suicidal poisoning (11). Malathion is a dimethyl-organophosphate with a low toxicity in humans. However, many fatal human ingestions of malathion have been documented in the literature, with the lethal doses estimated to range from $350 \mathrm{mg} \mathrm{kg}^{-1}$ to $1000 \mathrm{mg} \mathrm{kg}^{-1}$ (12). In addition to atropine, oximes, and supportive measures, FFP was administered during two days. A prompt increase of $\mathrm{BuChE}$ activity and volume restitution containing albumin eliminated the poison. This was followed by a clinical recovery, which was ascribed to the beneficial effects of FFP therapy, primarily induced by supplemented $\mathrm{BuChE}$ and albumin.

\section{CONCLUSION}

The patient with severe malathion poisoning was successfully treated by atropine, oximes, and FFP. The potentially beneficial effects of FFP are an increase of $\mathrm{BuChE}$ activity, colloid volume replacement, and rapid elimination of OPs. We believe that FFP may have helped in this case and that it could be used as a supplement in acute OP poisonings, especially when oximes are not available. 


\section{Acknowledgements}

This work was supported by the Ministry of Education, Science and Technological Development of the Republic of Serbia (Projects OI 176018 and III 46009).

\section{REFERENCES}

1. Eddleston M, Buckley NA, Eyer P, Dawson AH. Management of acute organophosphorus pesticide poisoning. Lancet 2008;371:597-607. doi: 10.1016/S0140-6736(07)61202-1

2. Rahimi R, Nikfar S, Abdollahi M. Increased morbidity and mortality in acute human organophosphate-poisoned patients treated by oximes: a meta-analysis of clinical trials. Hum Exp Toxicol 2006;25:157-62. doi:10.1191/ 0960327106ht602oa

3. Doctor BP, Saxena A. Bioscavengers for the protection of humans against organophosphate toxicity. Chem Biol Interact 2005; $15: 167-71$.

4. Güven M, Sungur M, Eser B, Sari Ĭ, Altuntaş F. The effects of fresh frozen plasma on cholinesterase levels and outcomes in patients with organophosphate poisoning. J Toxicol Clin Toxicol 2004;425:613-9.

5. Pichamuthu K, Jerobin J, Nair A, John G, Kamalesh J, Thomas K, Jose A, Fleming JJ, Zachariah A, David SS, Daniel D, Peter JV. Bioscavenger therapy for organophosphate poisoning-an open-labeled pilot randomized trial comparing fresh frozen plasma or albumin with saline in acute organophosphate poisoning in humans. Clin Toxicol 2010;48:813-9. doi: 10.3109/15563650.2010.518970

6. Doctor BP, Maxwell DM, Ashani Y, Saxena A, Gordon RK. New approaches to medical protection against chemical warfare agents. In: Somani SM, Romano JA Jr, editors. Chemical warfare agents:toxicity at low levels. New York (NY):CRC Press; 2002. p. 191-214.

7. Li B, Schopfer LM, Hinrich SH, Masson P, Lockridge O. Matrix-assited laser desorption/ionization time-of-flight mass spectrometry assay for organophosphorus toxicants bound to human albumin at Tyr411. Anal Biochem 2007;361:26372. doi: 10.1016/j.ab.2006.11.018

8. Peeples ES, Schopfer LM, Duysen EG, Spaulding R, Voelker $\mathrm{T}$, Thompson CM, Lockridge O. Albumin, a new biomarker of organophosphorus toxicant exposure, identified by mass spectrometry. Toxicol Sci 2005;83:303-12. doi: 10.1093/ toxsci/kfi023

9. Güven M, Sungur M, Eser B. The effect of plasmapheresis on plasma cholinesterase levels in a patient with organophosphate poisoning. Hum Exp Toxicol 2004;23:3658. doi: 10.1191/0960327104ht462cr

10. Fulton JA. FFP in organophosphate poisoning:what's the secret ingredient? Clin Toxicol 2005;43:215. doi: 10.1081/ CLT-200053343

11. Zivot U, Castorena JL, Gariott JC. A case of fatal ingestion of malathion. Am J Forensic Med Pathol 1993;14:51-3.

12. Farago A. Fatal, suicidal malathion poisonings. Arch Toxicol 1967;23:11-6. doi: 10.1007/BF00577694 


\section{Sažetak \\ SVJEŽA SMRZNUTA PLAZMA KAO UČINKOVIT DODATAK ANTIDOTSKOJ TERAPIJI U SLUČAJU AKUTNOG OTROVANJA ORGANOFOSFATOM}

Unatoč napretku intenzivnog liječenja i specifične farmakološke terapije (atropin, oksim, diazepam), mortalitet u akutnim trovanjima organofosfatima (engl. Organophosphate, OP) nije se značajno smanjio. Cilj je bio upozoriti na ulogu svježe smrznute plazme (engl. Fresh frozen plasma, FFP) u liječenju akutnih otrovanja OP-ima. Nakon namjerne ingestije malationa, u bolnicu je primljen muškarac u dobi od 55 godina s miozom, somnolencijom, bradikardijom, mišićnim fascikulacijama, pukotima pri auskultaciji pluća i respiratornom insuficijencijom kao karakterističnim znacima trovanja organofosfatom, kao i inihibicijom eritrocitne acetilkolinesteraze (AChE) i plazmatske butirilkolinesteraze (BuChE). U krvi je potvrđena prisutnost malationa u koncentraciji od $18,01 \mathrm{mg} \mathrm{L}^{-1}$. Pored pratećih mjera (uključujući mehaničku ventilaciju tijekom četiri dana), primijenjena je antidotska terapija atropinom, oksimom pralidoksim-metilsulfatom $\left(\right.$ Contrathion $\left.^{\circledR}\right)$ i diazepamom, zajedno s FFP-om. Naglo povećanje aktivnosti BuChE (od $926 \mathrm{IU} \mathrm{L}^{-1}$ do $3277 \mathrm{IU} \mathrm{L}^{-1}$; referentna vrijednost od $7000 \mathrm{IU} \mathrm{L}^{-1}$ do $19000 \mathrm{IU} \mathrm{L}^{-1}$ ), eliminacija otrova s promptnom redukcijom koncentracije malationa, uz klinički oporavak, mogu se pripisati povoljnim učincima terapije FFP-om kao adjuvansom. FFP osigurava BuChE, povećani sadržaj albumina i nadoknadu volumena, zbog čega se može koristiti kao alternativni način liječenja akutnih trovanja OP-ima, posebno kada nam nisu dostupni oksimi.

KLJUČNE RIJEČI: acetilkolinesteraza, albumin, butirilkolinesteraza, malation, oksimi

\section{CORRESPONDING AUTHOR:}

Prof. Biljana Antonijević

Department of Toxicology "Akademik

Danilo Soldatović", Faculty of Pharmacy,

University of Belgrade

11000 Belgrade, Serbia

E-mail:abiljana@pharmacy.bg.ac.rs 